\title{
Older Americans Working More, Retiring Less
}

\author{
ANNE SHATTUCK
}

A cross the last half of the twentieth century, a growing proportion of older working Americans withdrew from the labor force to spend their later years in leisure. Our three-part retirement income system-Social Security, private pensions, and personal savings-along with health insurance through Medicare, gave rise to retirement as we know it and contributed to a dramatic decline in poverty rates among the elderly. In 1959, 35 percent of Americans over age 65 lived below the poverty level, but by 1990, this rate had fallen to 12 percent. ${ }^{1}$ In 2008 , it stood at 10 percent. $^{2}$

As retirement became a possibility for more Americans, labor force participation rates of older Americans declined. The labor force participation rate of men age 70 and over fell from 21 percent in 1963 to 11 percent in 1990. The rate for women age 70 and older decreased from 5.9 percent in 1963 to 4.7 percent in $1990 .^{3}$ The trend toward earlier retirement occurred despite an increase in longevity over this period. From 1960 to 1990, the average life expectancy of Americans at age 65 (both sexes and all races) grew by three years. ${ }^{4}$ Thus, the average American was spending more years in retirement than ever before. For workers retiring at age 62 between 1990 and 1995, men could expect to live another seventeen years, and women, another twenty-one years. ${ }^{5}$

Since the early 1990s, however, the trend toward earlier retirement has begun to change. Many older Americans are staying in the labor force longer. When this change first became apparent, it was unclear whether it would be a temporary halt or a reversal of the decades-long decline in work at older ages. ${ }^{6}$ However, recent data indicate that the proportion of older adults working for pay is still growing. Although the trend began in the 1990s, the current economic recession may be an important reason that it continues.

This brief provides a portrait of recent trends in labor force participation among Americans age 65 and older by gender, education level, and marital status. ${ }^{7}$ It also considers differ-

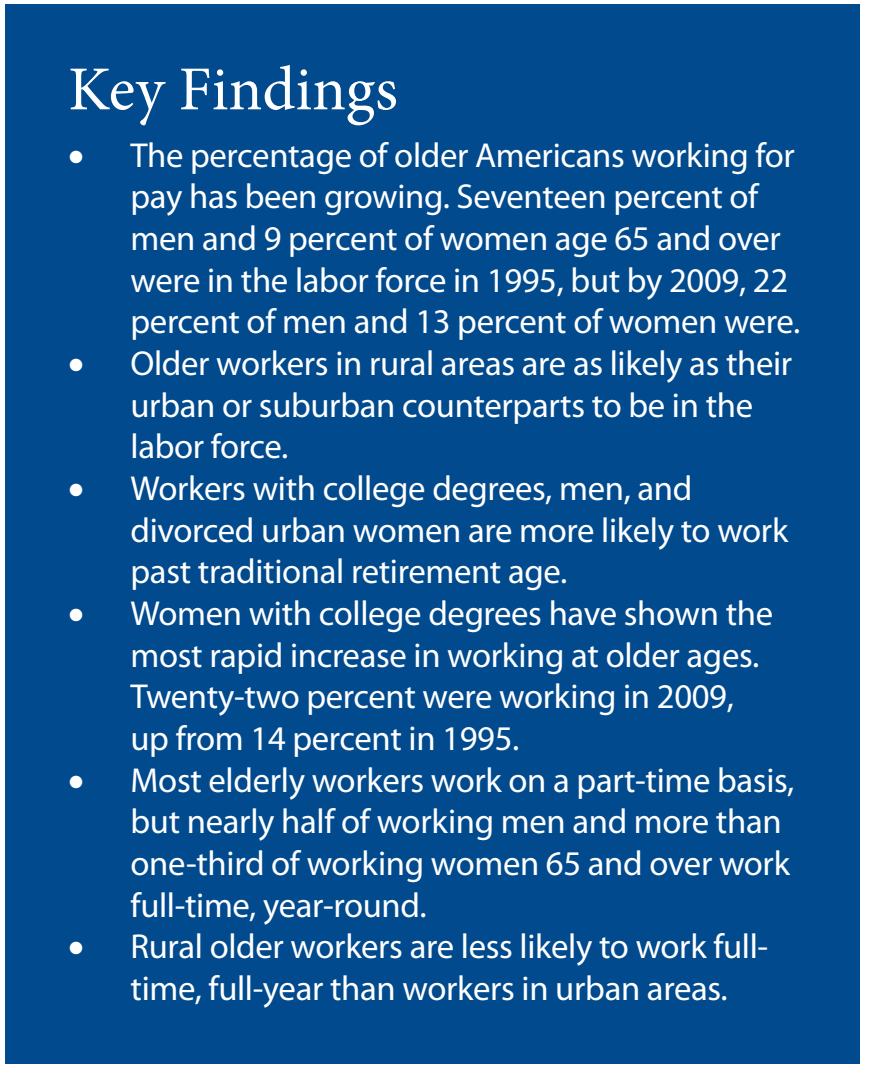

ences by rural or urban residence. ${ }^{8}$ In this brief, individuals are considered to be in the labor force or "working" if they are currently working for pay, full-time or part-time, or if they are unemployed and looking for work. The unemployed comprise only a small fraction of this group-less than 8 percent of workers over 65 in 2009. 
Figure 1. Percent of older Americans in labor force BY AGE AND SEX, 1995-2009

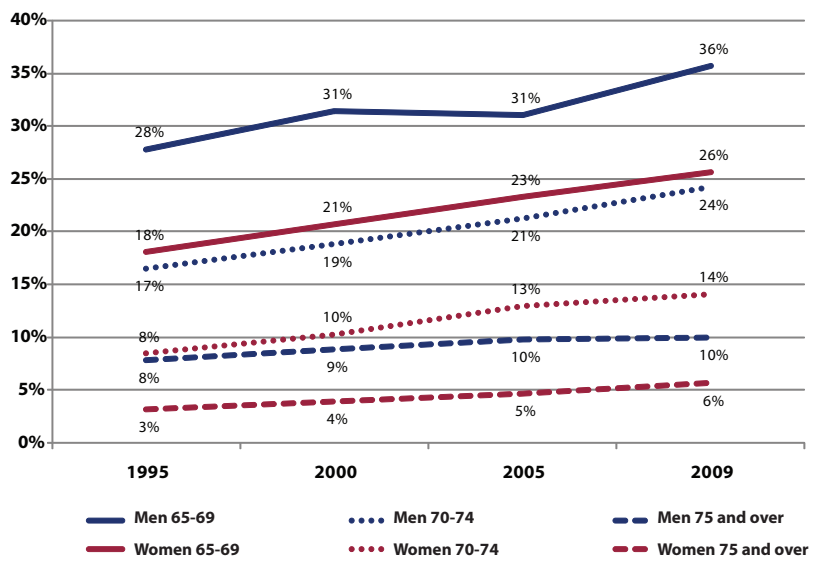

Source: Current Population Survey, Annual Social and Economic Supplement, 1995, 2000, 2005, and 2009

\section{Men and Women Work Longer in both Rural and Urban Areas}

Figure 1 shows that from 1995 to 2009, both older men and women were working longer. In early 2009 , more than one-quarter of women and more than one-third of men between ages 65 and 69 were in the labor force. For 70 - to 74 year olds, 14 percent of women and 24 percent of men were working in early 2009 . These two age groups have had the largest increases among those age 65 and older. Among men, labor force participation rates in the two groups increased by an estimated 8 and 7 percentage points, respectively, while women's rates in these groups grew by about 8 and 6 percentage points, respectively. Five percentage points of the eight-point increase for 65- to 69-year-old men came between 2005 and 2009, a period that includes the start of the current recession. Although relatively few Americans age 75 and older work, the number of working women in this age bracket roughly doubled over the period from 3 to 6 percent, a statistically significant increase. The increase in numbers of those working past age 65 is similar in rural, suburban, and urban places (see Table 1).

Table 1. Labor Force Participation for Ages 65 and Over by Place

\begin{tabular}{lc|cc|c} 
& \multicolumn{2}{c}{ MEN } & \multicolumn{2}{c}{ WOMEN } \\
\cline { 2 - 5 } & $\mathbf{1 9 9 5}$ & $\mathbf{2 0 0 9}$ & $\mathbf{1 9 9 5}$ & $\mathbf{2 0 0 9}$ \\
\cline { 2 - 5 } RURAL & 17.3 & 21.6 & 9.3 & 13.0 \\
SUBURBAN & 17.8 & 22.8 & 9.4 & 14.0 \\
CENTRAL City & 16.5 & 22.3 & 8.1 & 12.9 \\
\cline { 2 - 5 }
\end{tabular}

Source: Current Population Survey, Annual Social and Economic Supplement, 1995 and 2009.

\section{Those with More Education Work Longer}

Although Americans are working longer in both rural and urban areas, the likelihood of being in the labor force varies by personal characteristics. The more education a worker has, the more likely he or she is to continue working at older ages, and this is true for both rural and urban workers. College graduates have the highest participation rate among those age 65 and over. (See Figure 2) Men's rates are considerably higher than women's, but both men and women show the same dramatic increase with higher levels of education. The greater probability of more educated individuals to be in the labor force is an extension of pre-retirement patterns. Among those age 45 to 64, the likelihood of working increases with education for both men and women. ${ }^{9}$

Among older women, education is also associated with the growth in labor force participation between 1995 and 2009. During this period, labor force participation rates increased most rapidly for women with the most education. Figure 3 shows that the rate for non-college graduate women increased by 4 percent, while the rate for collegeeducated women grew by 8 percent. Five points of this increase came between 2005 and 2009, which includes the beginning of the recession. Men's rates grew slightly and by similar amounts at each education level.

Several factors might help to explain why more educated workers tend to work longer despite the likelihood that they are better positioned financially, on average, to leave the labor force. More highly educated workers tend to be healthier, their earnings tend to be higher, and they are

Figure 2. LABOR FORCE PARTICIPATION AMONG ADULTS AGE 65 AND OVER BY EDUCATION AND GENDER, 2009

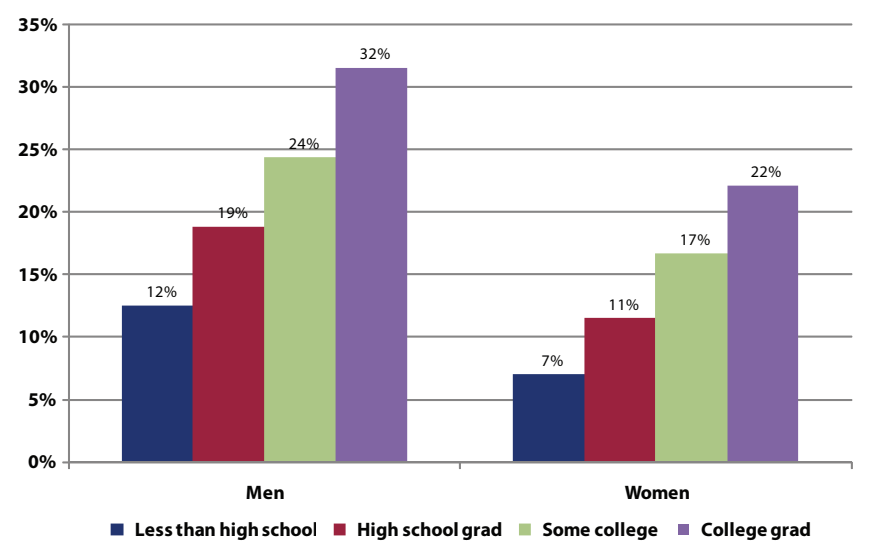

Source: Current Population Survey, Annual Social and Economic Supplement, 2009 
Figure 3. ChANGE IN LABOR FORCE PARTICIPATION OF WOMEN AGE 65 AND OVER BY EDUCATION, 1995 TO 2009

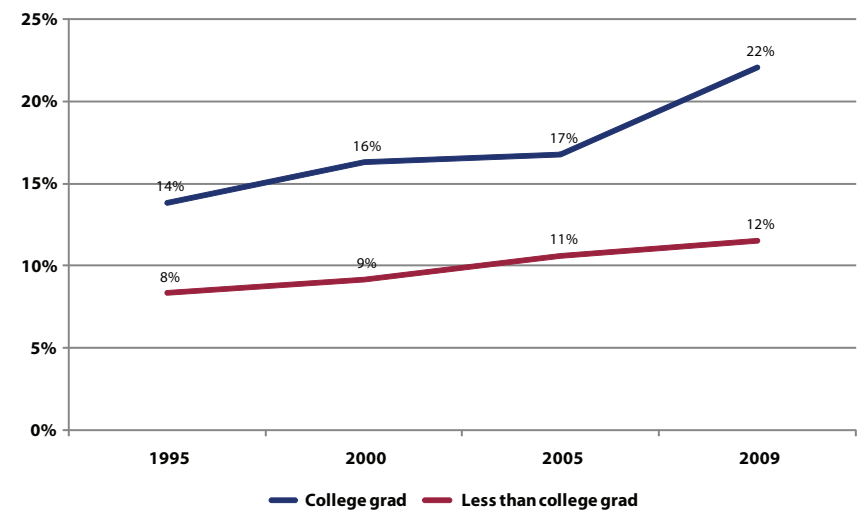

Source: Current Population Survey, Annual Social and Economic Supplement, 1995, 2000, 2005, and 2009

less likely to hold physically demanding jobs that become difficult to perform with advancing age. Their prospects for employment are better than those of their less-educated peers since they are viewed more favorably by employers than are less-educated older workers. ${ }^{10}$ In addition, highly educated workers may simply be more likely to enjoy the kind of work they do and wish to continue doing it. Conversely, lower education is associated with worse health, and poor health is a major reason for exiting the labor force at older ages. ${ }^{11}$ Moreover, Social Security replaces a higher proportion of pre-retirement earnings for low-wage workers compared with high-wage workers. This may make retirement more attractive to less-educated workers who earn less.

\section{Divorce Drives Many Women to Work Longer}

In addition to education, marital status is also tied to working at older ages but primarily for women. As Figure 4 shows, divorced and separated older women work at significantly higher rates than either married, widowed, or never married women. Of divorced or separated women, 26 percent are still in the labor force compared with 14 percent of married women, 19 percent of never married, and 8 percent of widowed older women. In one of the few distinctions between urban and rural areas, rural divorced or separated older women are less likely to work than their urban peers. While 27 percent of urban divorced or separated older women work, in rural areas, only 19 percent of rural older women do.
Divorced women, especially those who have raised children outside of marriage, are, on average, less financially secure in later life than married women or men, and this may explain their higher rates of labor force participation. ${ }^{12}$ On average, women accrue fewer retirement assets over their lifetime, and they have lower Social Security benefits from their own working years because their earnings are typically lower than men's. Also, many take time off from the labor force for childrearing or other unpaid family work. Without the economic benefit of a spouse's retirement assets, many divorced older women may need to continue working for pay.

The percentage of older women who are divorced has been rising. In 1995, 7 percent of women age 65 and older were divorced, but in 2009, 12 percent were. ${ }^{13}$ The increasing proportion of divorced women may be one factor contributing to the increase in the overall labor force participation rate for all older women.

Men, in contrast, show few differences by marital status. Only widowed men have a significantly lower rate of labor force participation (as do widowed women). The lower labor force participation rates of widows and widowers are not surprising because they tend to be older than non-widowed men and women in the 65 and over age group. ${ }^{14}$

FIGURE 4. LABOR FORCE PARTICIPATION BY MARITAL STATUS FOR AGES 65 AND OVER, 2009

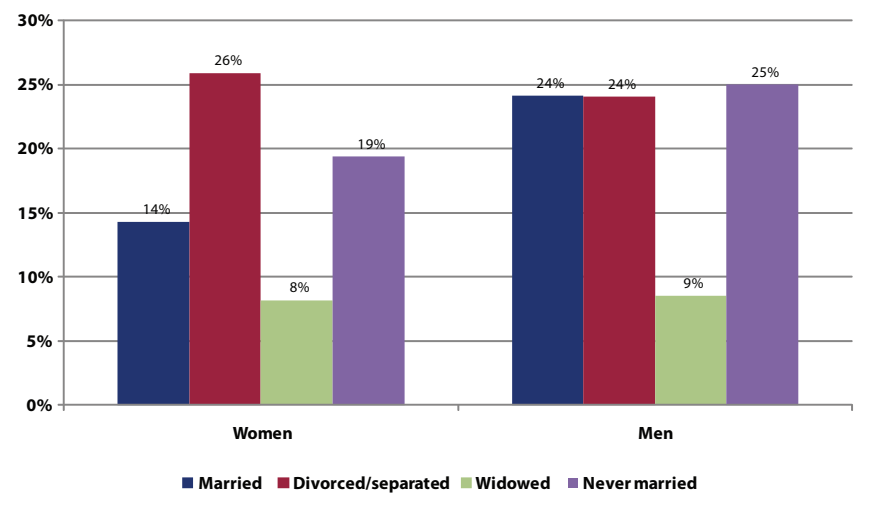

Source: Current Population Survey, Annual Social and Economic Supplement, 2009 


\section{Most Work after Age 65 is Part-Time, but Full-Time Work is on the Rise}

Although older Americans are working longer, most are not in full-time, year-round jobs. Previous research indicates that older workers often work fewer hours than their previous career jobs required, and they often work for wages that are substantially lower than their career wages. ${ }^{15}$ However, a substantial minority of older workers does work fulltime, year-round, and their proportion among the ranks of older workers has been growing. As Figure 5 shows, nearly one-half of working men (48 percent) and more than a than one-third of working women (37 percent) age 65 and over had full-time, year-round schedules in 2008. This is significantly more than in 1994 when 38 percent of older men and 23 percent of older women in the labor force were full-time, year-round workers. The increase has taken place in both rural and urban areas, although in most years, rural older workers have been slightly less likely to work full-time, yearround that their urban counterparts. Rural older worker's lower rates of full-time, year-round schedules may reflect a higher proportion of seasonal jobs in rural areas.

Figure 5. Full-Time, Full-year StATUS AMONG WORKerS AGE 65 AND OLDER, 1994 TO 2008

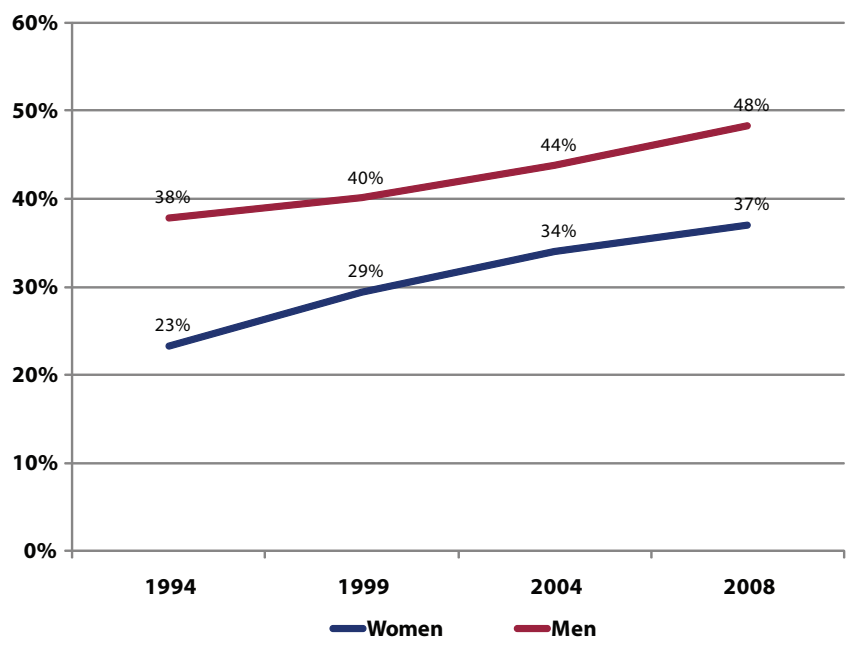

Source: Current Population Survey, Annual Social and Economic Supplement, 1995, 2000, 2005, and 2009

\section{Discussion and Implications}

Increasing proportions of older men and women are remaining in the paid labor force past traditional retirement age, and this trend is taking place in rural and urban areas. Working for pay is more likely for men, for college-educated individuals, and for divorced women. The fastest increase in labor force participation among older Americans since 1995 has been for college-educated women.

There are several reasons why workers may be delaying retirement. Older Americans are living longer, they are healthier than in previous generations, and jobs have become less physically demanding. ${ }^{16}$ Recent changes to Social Security rules also encourage more years of work. The normal retirement age, the age at which workers can collect their full monthly benefit, is gradually increasing from age 65, for those born in 1937 or earlier, to age 67, for those born in 1960 or later. ${ }^{17}$ Also, in 2000, the earnings test that limited how much workers could earn from paid work and still collect their full monthly Social Security benefit was eliminated for workers who had reached normal retirement age (66 for those retiring now).$^{18}$ However, workers who choose to delay collecting Social Security receive "delayed retirement credits," which increase the amount of their benefit when they do retire. The value of delayed retirement credits has increased in recent years, ${ }^{19}$ which may also be encouraging people to work longer.

The trend toward work at older ages is likely to continue into the future. The three-part retirement income system (Social Security, private pensions, and personal savings) that made retirement a normal phase of life is deteriorating and will provide less financial security to future generations. Employers who still offer pension plans increasingly offer defined contribution retirement plans, such as $401 \mathrm{ks}$, rather than traditional defined benefit plans that pay a specified benefit for life. This will leave many workers who have employersponsored pension plans with insufficient savings to see them through retirement. More significant, though, is the fact that about one-half of private sector workers are not covered by any employer-sponsored retirement plan at all. ${ }^{20}$ In addition, many Americans used equity in their homes for consumption during the recent housing price boom from 2000 to $2007 .{ }^{21}$ The subsequent real estate market collapse and the ongoing recession will cause many to reach retirement age with reduced net worth. In short, many more Americans will need to work longer.

If more older Americans are to work longer, employers may need to adapt to their needs. Older workers often prefer fewer hours and flexible scheduling, but not all employers provide such an option. ${ }^{22}$ In addition, employers must be willing to hire and retain older workers. Survey results indicate that many employers view older workers as more costly. For whitecollar workers, this is balanced somewhat by a perception that they are more productive than younger workers. Non- 
white-collar workers, on the other hand, are not seen as any more productive than their younger counterparts and thus their employment prospects may be more limited than those of white-collar peers. ${ }^{23}$ Furthermore, despite legal protections, there is evidence of continuing age discrimination in the U.S. labor market. ${ }^{24}$

If, as predicted, more and more Americans arrive at old age with insufficient assets for retirement, continued employment may be a way for many to fill the financial gap. Unfortunately, it may turn out that those who could most benefit from continued employment may be least likely to continue working. Evidence indicates that lower-wage workers are not saving enough for retirement, ${ }^{25}$ but low-wage earners are also more likely to suffer from poor health and higher rates of disability, factors that may keep them out of the labor force.

Policy changes, such as those proposed recently by President Obama - a workplace retirement savings plan for workers not already covered by an employer-sponsored plan and an increase in the tax credit for retirement savings by families earning less than $\$ 85,000$ - may be needed to help avert a reversal in the decades-long decline in poverty among the elderly.

\section{Data}

Data used in this brief are from the Current Population Survey, Annual Social and Economic Supplements (CPS ASEC) of 1995, 2000, 2005, and 2009. Labor force participation rates were calculated from monthly CPS variables and refer to the work status of the respondent in the week preceding the survey. Data on full-time, year-round status is from the March Supplement Questionnaire and refers to the calendar year preceding the survey. Comparisons mentioned in the text are significant at the .05 level.

Alexander, J. Trent, Michael Davern, and Betsey Stevenson have raised questions regarding the accuracy of estimates for individuals age 65 and older using data from some U.S. Census Bureau public use microdata samples, including the 2005 and 2009 CPS ASEC. ${ }^{26}$ To assess whether the problems they describe might affect the results presented here, we compared 2005 CPS ASEC labor force participation rates for three age groups ( 65 to 69,70 to 74 , and 75 and over) by sex against labor force participation rates published in the 2005 American Community Survey Detailed Table B23001, available on the U.S. Census Bureau's American FactFinder Web site. (ACS data are not yet available for 2009.) Like the CPS, the ACS is a nationally representative survey of American households. Detailed tables published by the U.S. Census Bureau on the ACS Web site are based on the full ACS data file, which is not subject to the disclosure avoidance techniques that are used in microdata products released to the public and that appear to be the source of the inaccuracies described by Alexander and his colleagues. In our comparison across the CPS and ACS samples, 2005 labor force participation rates for these age groups for both men and women were very similar. Using 95 percent confidence intervals calculated for both sets of estimates, there were no significant differences between the two samples for five of the six age-sex groups. Only the rate for men age 65 to 69 , which was obtained using the CPS, was slightly lower than the published ACS rate (31 percent compared with 33.7 percent). Published ACS tables do not contain detail on labor force participation by age and by marital status, education, and rural versus urban residence, so comparisons between the ACS and CPS on these variables could not be made. 


\section{Endnotes}

1. Federal Interagency Forum on Aging-Related Statistics, 2008, available at http://www.agingstats.gov/ agingstatsdotnet/Main_Site/Data/2008_Documents/tables/ Tables.aspx.

2. Current Population Survey, Annual Social and Economic Supplement, 2009.

3. Federal Interagency Forum on Aging-Related Statistics, 2008, available at http://www.agingstats.gov/ agingstatsdotnet/Main_Site/Data/2008_Documents/tables/ Tables.aspx. The smaller decrease in women's rates reflects two separate and offsetting trends. Although many working women were also retiring earlier, more women were in the labor force. The increasing proportion of women in the workforce tended to counteract the trend toward earlier retirement, thus older women's labor force participation declined only slightly. See also Leora Friedburg, "The Recent Trend towards Later Retirement" (Boston: Center for Retirement Research at Boston College, Issue in Brief Series 9, March 2007).

4. Centers for Disease Control and Prevention, National Center for Health Statistics, available at http://www.cdc.gov/ nchs/data/hus/hus08.pdf\#026.

5. Murray Gendell, "Retirement Age Declines Again in 1990's," Monthly Labor Review (U.S. Bureau of Labor Statistics, October 2001), available at http://www.bls.gov/ opub/mlr/2001/10/art2exc.htm\#2a.

6. Leora Friedberg, “The Recent Trend towards Later Retirement” (Boston: Center for Retirement Research at Boston College, Issue in Brief Series 9, March 2007).

7. Race and Hispanic ethnicity were also analyzed, but there were no significant differences in the labor force participation of adults age 65 and over by race and ethnicity, so the results are not been presented here.

8. In this brief, "rural" consists of areas designated by the U.S. Census Bureau as non-metropolitan. "Central city" consists of the principal city of a core-based statistical area (CBSA), while "suburban" is defined as the balance of a CBSA outside the principal city. The term "urban" is used here to refer to both central city and suburban areas combined.

9. According to the Current Population Survey, Annual Social and Economic Supplement 2009, 88 percent of 45- to 64-year-old men with a four-year college degree were in the labor force compared with 76 percent of high school graduates. For women in that age range, 78 percent of college graduates versus 66 percent of high school graduates were working in 2009.
10. Alicia H. Munnell, Steven A. Sass, and Mauricio Soto, "Employer Attitudes towards Older Workers: Survey Results," Issue Brief, Work Opportunities for Older Americans Series 3 (Boston: Center for Retirement Research at Boston College, 2006), available at http://crr.bc.edu/ images/stories/Briefs/wob_3.pdf.

11. Steven Haider and David Loughran, "Elderly Labor Supply: Work or Play?” Working Paper No. 2001-04 (Boston: Center for Retirement Research at Boston College, 2001), available at http://crr.bc.edu/working_papers/elderly_labor_ supply_work_or_play_.html.

12. Richard W. Johnson and Melissa M. Favreault, "Economic Status in Later Life Among Women Who Raised Children Outside of Marriage," Journal of Gerontology 59B (2004): S315-S323.

13. Current Population Survey, Annual Social and Economic Supplement 1995 and 2009.

14. The median age of widowed men 65 and older is 80 compared with 72 for non-widowed men. For widowed women 65 and older, the median age is 79 compared with 71 for the non-widowed. Current Population Survey, Annual Social and Economic Supplement 2009.

15. Haider and Loughran, "Elderly Labor Supply."

16. John C. Henretta, "The Future of Age Integration in Employment," The Gerontologist 40(3) (2000): 286-292; Alicia H. Munell, "Policies to Promote Labor force Participation of Older People," Work Opportunities for Older Americans Series, Working Paper No. 2, (Boston: Center for Retirement Research at Boston College, January 2006).

17. Workers can still retire as early as age 62 , but they receive a smaller proportion of their full benefit than in the past. See http://www.socialsecurity.gov/OACT/ProgData/nra.html.

18. The Social Security normal retirement age is gradually being increased from 65 for those born in 1937 or earlier to 67 for those born in 1960 or later. See http://www. socialsecurity.gov/OACT/ProgData/nra.html.

19. Social Security Administration, http://www. socialsecurity.gov/OACT/quickcalc/early_late.html.

20. Alicia H. Munell, and Laura Quinby, "Pension Coverage and Retirement Security," Issue in Brief No. 8-1 (Boston: Center for Retirement Research at Boston College, December 2009). (http://crr.bc.edu/images/stories/Briefs/ ib_9-26.pdf)

21. Alicia H. Munnell and Mauricio Soto, "The Housing Bubble and Retirement Security," Issue in Brief No. 9-26 (Boston: Center for Retirement Research at Boston College, September 2008). 
22. Marcie Pitt-Catsouphes and Michael A. Smyer, "One Size Doesn't Fit All: Workplace Flexibility," Issue Brief No. 5 (Boston: Center on Aging and Work: Workplace Flexibility at Boston College, 2006), available at http://agingandwork. bc.edu/documents/IB05_OneSizeDoesntFit_000.pdf.

23. Munnell, Sass, and Soto, "Employer Attitudes."

24. Joanna Lahey, "Age, Women, and Hiring: An Experimental Study," Working Paper No. 2006-23 (Boston: Center for Retirement Research at Boston College, November 2006); Marc Bendick, Charles W. Jackson, J. Horacio Romero, "Employment Discrimination Against Older Workers: An Experimental Study of Hiring Practices," Journal of Aging and Social Policy 8(4) (1996): 25-46.

25. Eric M. Engen, William G. Gale, and Cori Uccello, "Lifetime Earnings, Social Security Benefits, and the Adequacy of Retirement Wealth Accumulation," Working Paper No. 2004-10 (Boston: Center for Retirement Research at Boston College, April 2004).

26. J. Trent Alexander, Michael Davern, and Betsey Stevenson, "Inaccurate Age and Sex Data in the Census PUMS Files: Evidence and Implications," Working Paper 15703 (Cambridge, Ma: National Bureau of Economic Research, 2010), available at http://www.nber.org/papers/ w15703.

\section{About the Author}

Anne Shattuck is a research assistant at the Carsey Institute and a doctoral candidate in sociology at the University of New Hampshire (anne.shattuck@unh.edu).

\section{ACKNowledgments}

The author wishes to thank Marybeth Mattingly of the Carsey Institute; Richard Johnson of the Urban Institute; John C. Scott of the University of North Carolina, Chapel Hill; and Barbara Ray of Hired Pen for their helpful comments on earlier drafts of this brief. 


\section{ANIVERSITY}

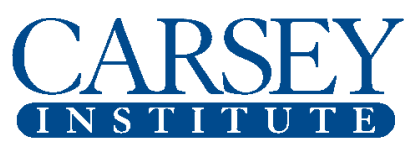

Building knowledge for families and communities

The Carsey Institute conducts policy research on vulnerable children, youth, and families and on sustainable community development. We give policy makers and practitioners timely, independent resources to effect change in their communities.

This research was supported by the Annie E. Casey Foundation, the W.K. Kellogg Foundation, and an anonymous donor.

Huddleston Hall

73 Main Street

Durham, NH 03824

(603) $862-2821$

www.carseyinstitute.unh.edu 